\title{
蘆花淺水荘庭園の筑造過程とデザイン
}

\section{The Construction Process of Rokasensui-Soh Garden and its Design}

\author{
小野健吉* \\ Kenkichi ONO
}

\begin{abstract}
摘要 : 蘆花淺水荘は, 近代京都画壇で活躍した日本画家・山元春擧が, 郷里滋賀県大津市の琵琶湖
畔に営んだ別荘である。庭園は，大正 $4 \sim 6$ 年ごろを中心に，春擧の指示のもと京都の庭師・本井政 五郎らにより作庭された。築造時の記録, 築造後間もない時期の写真・図面・文献, 関係者の証言な どから，この庭園が建築と並行して築造されたこと，風景画にすぐれていた春舉が絵を描く感覚でこ の庭園のデザインに取り組んだこと，琵琶湖を視覚的にも利用の上でも主たる構成要素とする傑出し たデザインの写実的風景式庭園であったことなどを確認した。
\end{abstract}

\section{1.はじめに}

盧花淺水荘は, 近代京都画壇において竹内栖鳳と並ぶ中心的な 存在であった日本画家・山元春擧 (明治 $4 \cdot 1871$ 昭和 $8 \cdot 1933$ ) が故郷の滋賀県膳所町（現在の滋賀県大津市中庄）に棠んだ別荘 である。大正 3 年 (1914）に土地を入手 ${ }^{1)}$ 後, ただちに建築・庭 園の築造にとりかかり, 最終的には大正 12 年 (1923) に完成し ている。築造当初, 周辺は田園地帯で, 琵琶湖に直接面したこの 別荘は, 琵琶湖や対岸の三上山などすぐれた眺望を恣にしていた。 現在, 周囲には中高層の建築が建ち並び, 敷地と琵琶湖を分断す るかたちで自動車道路が通るなど，その周辺環境の悪化は著しい。 しかし，敷地内は建築・庭園とも良好に保存されており，築造当 時の記録や写真といった一次資料も山元家に保管されている。本 稿では, この記録や写真をもとに, 庭園の築造過程に考察を加え, そのデザインの特色を明らかにすることを試みたい。さらに，日 本画家による庭園として, 蘆花淺水荘の近代日本庭園史における 意義についても言及したい。

\section{2. 京都本邸の庭園}

山元春擧による蘆花淺水荘の作庭を考えるうえで見逃せないの は, 明治 44 年 (1911) の京都本邸築造である。春擧がはじめて 持ったこの自邸は, 京都市上京区高倉丸太町下る坂本町 702 にあっ た。この屋敷の庭作りについて春擧の長男山元清秀は「…作庭 の意欲が涌いたか, 町中のこととてさのみ広くない場所に, 不釣 合いと思えるような大きな岩を数個巧みに配置して, 渓谷, 深淵 を連想するように作り, 夏には鮎を泳がせて楽しんだ。」党と回 想している。山元家に残る写真 1 を見ると, 緑先の大振りの沓脱 石をかすめるようにうがたれた流れを中心とした庭で，岸には大 石を据えマツやカエデを配植していたことがわかる。近世の京都 の庭園によく見られる池（あるいは枯池）と築山という組み合わ せではなく, 流れを用いている点にこの時代の京都の庭園らしい 好みぶを見てとることができる。この庭の作庭にたずさわったの は同じ坂本町在住の庭師本井某とその末弟・由之助であった ${ }^{4)}$ 。

なお，山元家には明治末年すなわち本邸新築のころ春擧が描い た京都・龍安寺石庭の図が残されており, 当時, 春擧が庭園に対 する興味を高めていたことをうかがわせる。そして，こうした庭 園に対する興味がそのすぐ後に続く蘆花淺水荘の作庭へとつながっ ていったと考えてよかろう。

\section{3 . 蘆花淺水茫築造記録}

山元家には, 『別荘入費及祝品控』が保管されている。この記 録は春擧夫人の手によるもので, 大正 3 年（1914） 9 月の土地購
入からはじまり, 蘆花淺水荘築造にかかわる一切の支出を記載す るとともに, 蘆花淺水荘での催しの招待客の名簿, 祝儀の明細な どについても記載している。ここでは，この記録から主に庭園関 連の記載事項を拾い出し，作庭時の状況を追跡してみよう。

蘆花淺水荘の作庭に主としてたずさわった庭師は本井政五郎で ある ${ }^{5)}$ 。本井政五郎は, 前述した春擧の京都本邸の作庭にたず さわった本井某の弟（由之助の兄）にあたり，京都市夷川柳馬場 上がるで同じく造園業を営んでいた ${ }^{6)}$ 。本井の名がはじめて見え るのは, 大正 4 年（1915） 6 月分支払の「壱百九十九円七十銭 · 本井へ石代」である。主屋の上棟が同じ大正 4 年 6 月 ${ }^{1}$ であるこ とから, 蘆花淺水荘築造当初から建築と平行して作庭がおこなわ れ，本井政五郎がかかわっていたことがわかる。この年の作庭関 連の記載を列記すると以下のとおりである。

「七月三十日 · 壱百武拾六円五十銭 ·本井手間代壱百一人但し 一人壱円武十銭 ${ }^{8)} 」 「$ 七月三十日 · 九拾円也 - 同石代」「八月三十 日 - 拾五円 ·本井 ·石代残り」「十月三十日 - 三拾円 - 本井手間 代」「十月三十日 - 武十四円十五銭 ·同石代」「十二月三十一日 · 九拾二円六十鐿 ·山科植木や」「十二月三十一日 · 壱百三十四円 六十銭・本井石及手間代」

この年, 本井へ石代及び手間代として計 619 円 95 銭, 山科 ${ }^{9)}$ 植木屋へ 92 円 60 銭を支出しており, 合計すると 712 円 55 銭が 作庭関連の支出となっている。この年の総支出額が 7,474 円 61 銭であるから，作庭関連支出の占める割合は $9.5 \%$ である。また， 本井への支払はすべて石代・手間代となっており，この記録を読 む限り, 本井は景石を納入し職人を出していただけで, 植物材料 の納入はしていなかったものと推測できる。

なお， 7 月 30 日の記載にある「手間代一人壱円武十銭」は興 味深い。蘆花淺水荘の建築を担当したのは京都の大工・橋本嘉三 郎であるが, 大工の手間貨に関する記載はこの記録にはない。し

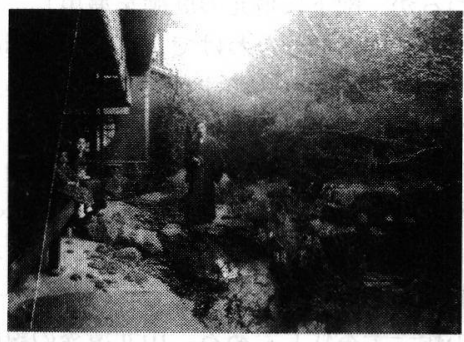

写真 -1 京都本邸の庭 (大正 5 年 $)$

*奈良国立文化財研究所平城宮跡発掘調査部 
かし, 大正 4 年、京都における大工 1 人 1 日当たりの平均的な手 間貨は 1 円ちょうど0; であることから本井の造園職人は, 大工以 上の手閒賃を取っていたことがわかる。ちなみに，大正 5 年の東 京における白米 $10 \mathrm{~kg}$ の標準小売価格は 1 月20銭㕵である。

続いて大正 5 年 (1916) の作庭関連の支出を拾い出してみよう。

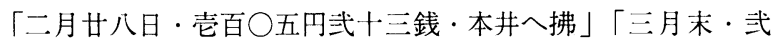
百参拾九円六十七銭 ·柳 - 本井」「三月末 · 武拾四円 - 町内 · 本 井」「四月末 ·壱百八十円拾銭・本井」「四月末·武拾五円 - 山科 植木ヤ」「五月·壱百七拾七円六十七銭·本井」「六月三十日 ·武 百二十二円八銭五厘 ·本井」「七月 - 壱百廿九円九十銭 ·柳 · 本 井」「(八月か? ）・ 三拾九円・柳 - 本井」「十二月 - 拾武円 - 松 の木㚃本」「十二月・壱百円・坂本植木買入」

作庭関連支出合計は 1254 円 65 銭 5 厘である。この年の総支出 額 4259 円 81 銭 5 厘に対する割合は $29.5 \%$ となり，作庭が大き な比重を占めていたことがわかる。ここで注目しておきたい点が 3点ある。まず，「町内・本井」と「柳・本井」という記載であ る。前述のとおり, 藘花淺水荘の作庭を担当したのは京都・夷川 柳馬場の本井政五郎であったが, 春擧の京都本邸の作庭にたずさ わった本井由之助も一時的にこの蘆花淺水荘の造園にかかわった ことがこれでわかる。第二は，「十二月・拾武円・松の木壱本」 という記載である。この『別荘入費及祝品控』のなかで単木とし て記載されているのはこのマツ 1 本だけである。視点を変えれば, 蘆花淺水荘ではそれほど高価な庭木は購入していないということ にもなる。なお,このマツは, 仏堂の北側に植えられていたもの である ${ }^{12)}$ 。第三は, 本井の名が支払相手として記載されているの はこの年が最後であるという点である。翌大正 6 年以降は, 本井 にかわって「植清」の名が出てくる。「植清」とは, 本井の指揮 下でこの庭の作庭にたずさわっていた地元大津の庭師・木村清太 郎のことである ${ }^{13)}$ 。すなわち, 蘆花淺水荘の作庭は大正 5 年を最 後に本井の手をはなれ木村清太郎の手にゆだねられているのであ る。これは,この年に庭園の主要部がおおむね完成し, 植栽など 一部を残すのみとなったことを示しているのであろう。

次に大正 6 年 (1917) の作庭関連の記載を見てみよう。

$\lceil$ 一月 · 壱百円 · 植清拂」「一月 ·拾壱円 - 等持院橋本 · 小松 一千本代」「二月·壱百三拾五円廿五銭・植清拂」「三月·壱百六 拾円 ·植清拂」「五月 $\cdot$ 八拾円武十壱銭 ·植清」「七月二日分 $\cdot$ 五 拾四円四十四銭五厘 ·植木屋」「九月 · 六円四十四銭 ·植清」「八 月分・拾八円九十一銭 - 植清」「十月 - 八円四十四銭五厘 ·植清 拂」「十一月 ·八円七十銭 ·植清拂」「十二月 -九拾七円 ·植清」

合計 680 円 40 銭で, 総支出 3530 円 43 銭に対して $19.3 \%$ であ る。この年の作庭関連支出の特徵は, 前述したように本井に代わっ て「植清」が支払相手として登場する，すなわち作庭を担当する ようになったことである。大正時代, 京都の庭師が他の地方に出 向いて作庭にたずさわることは，「植治」小川治兵衛の例 ${ }^{14}$ を見 てもわかるように，それほど稀なことではなかったようだ。本井 も京都からそう遠くないとはいえ大津まで出向いて蘆花淺水荘の 作庭にたずさわるが，配下に地元の庭師を雇用し，概ね完成した ところで後をその庭師に託したわけで, 京都の庭師の他の地方に おける仕事の進め方の一例として注目しておきたい。さらに, こ うした仕事の進め方が例外的でなかったとすれば, 近代の京都の 作庭技術が他の地方に伝播する一つの形態であったとも考えられ る。『別荘入費及祝品控」は, 支出の明細だけでなく上記のよう な事実を記録に残している点でも，重要な資料であるといえよう。 この年の記載のうちもう一つ注意を引くのは, 一一月・拾壱円・ 等持院橋本 · 小松一千本代」である。山元清秀の説明によれば, 11 円の内訳は 1 本 1 銭の松苗 1000 本と運搬料 1 円。これらの小 松は主庭の流れに沿った小築山に植えられたという ${ }^{15)}$ 。(写真 2) 大正 $7 \sim 9$ 年（1918１920）は仏堂などの建築工事が中心で作
庭関連の支出は記録されていないが，大正 10１2 年（1921～23） の「本屋改築費控」のなかでは作庭関連の支出が以下のとおり記 載されており，「植清」が全面的に担当していることがわかる。

$\lceil($ 大正十一年 $) \cdot$ 四月 · 参百七拾円 - 植清」「五月 . 壱百武十 武円六十銭」「八月世一日 - 四拾八円七十五銭 ·植清」「十月世日 · 参百武十円 ·植七」「十一月世日 - 武百四拾壱円七十八銭 ·植七」 $\lceil 十 二 月 世 一 日 \cdot$ 参百八拾壱円八十銭・植清」

ところで，この『別荘入費及祝品控』にはこれまで述べてきた ような工事費のほかに, 蘆花淺水荘で開いた催しの招待客の名簿 やその際の出費，さらに招待者からの祝品などが記載されている。

こうした記載によれば, 仏堂の開堂式は建仁寺の然雷老師, 相 国寺の獨山老師, 等持院の笠源長老ら 17 人を招いて, 大正 9 年 (1920) 11 月 23 日に催されている ${ }^{16)}$ 。さらに, その翌日の 11 月 24 日には茶会を開き 137 人を招待している ${ }^{17)}$ 。その中には飯田 新七, 西村惣左衛門, 平井仁兵衛, 土橋嘉兵衛, 岡田岩次郎, 大 橋正之助, 中井三郎兵衛など京都の有力な実業家の名が見える。 彼らはこの時代の京都の庭園の施主層としてそのデザインに少な からず影響を与えた人々である ${ }^{18\rangle}$ 。また, 春擧と親しかった図案 家の神坂雪佳や美術ジャーナリストの黒田天外の名も見える。神 坂は, 大橋正之助の松ヶ崎別荘無盡庵の庭をデザインするなど, この時代の京都の庭に深くかかわったし, 黒田天外は『名家歴訪 録』（1899）『江湖快心録』（1901）『續江湖快心録』（1907）など の著作のなかで, しばしば建築や庭園にふれるなどこうした分 野への造詣も深かった。この日の招待客の中には, 蘆花淺水荘の 造園を担当した本居(ママ)政五郎, 本井由之助の名も記録されて いる。蘆花淺水荘の作庭を担当したこの 2 人が, いわば庭に対す る目の肥えた招待客と, この庭について語り合ったであろうこと は想像にかたくない。

ところで, 祝品のリストを見ると,「本屋之祝品」(年月不記載) の中には庭園に用いる材料も散見する。

「庭石数個 - 其他置物燈籠 - 岡田岩次郎」「庭石大小十個植木 種々・森清太郎」「庭石大武個 ·井上/手水鉢三個 - 松盆栽 · 植 清」「庭石・椹木」「松ノ木壱本 ·南部」「松ノ木大小十数本 · 栗 田松二郎」

これらの材料も庭園の随所に用いられたのであろう。このうち 岡田岩次郎は, 京都・山科昆沙門山にあった彼の別荘・層翠庵か ら石を持参したものという ${ }^{19)}$ 。

\section{4 . 蘆花淺水荘庭園のデザイン}

蘆花淺水荘庭園の施工は, 上述のように当初は本井政五郎, 続 いて木村清太郎によって行われた。しかし，そのデザインは，作 庭に興味を持っていた施主春擧の主導によっていたことは言うま でもない20)。重森三玲は, 春擧と本井との関係について「本庭は 春擧画伯が何処までも自から好みを出すべく, 細心の注意を払は れ，画境にあると同じく細部に至るまで始終努力されたのであっ たが,是が施工は本位(ママ)政五郎氏であって,氏は又春擧画伯の

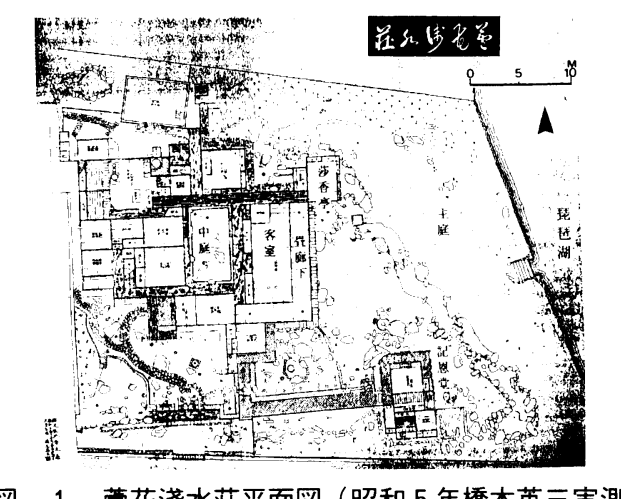

図一 1 痈花淺水荘平面図（昭和 5 年橋本英三実測） 


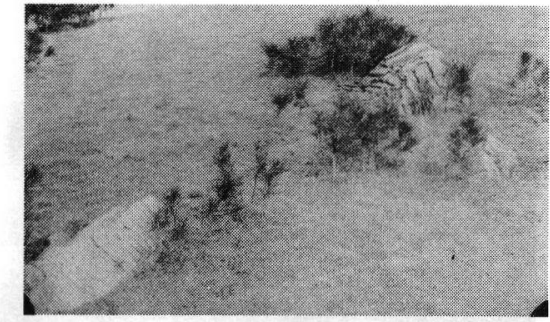

写真-2 蘆花淺水荘に植えられた小松 (大正6年)

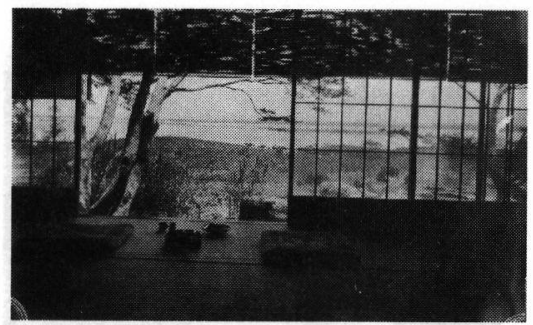

写真一 3 主屋客室からの庭景

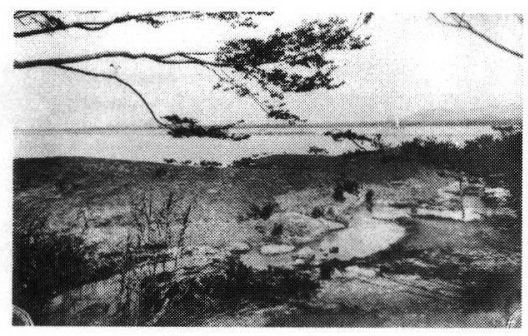

写真 -4 同左
好みを忠実に表現すべく努力されたのである。」」21) と述べている。

それでは, 蘆花淺水荘の築造間もないころの状況を具体的に再 現しつつ, そのデザインの特色を抽出してみよう。資料としては, 山元家に保存されている蘆花淺水荘の築造時及び築造後間もない 時期の写真や昭和 5 年 (1930) に橋本英三（大工・橋本嘉三郎の 子息）が作成した敷地全体の平面図（図 1 ）を用いる。

まず，敷地全体の平面図を見てみよう。これは，昭和 $7 \sim 8$ 年 （1932～33）に茶室「穂露」が敷地の北東部に建てられる以前の 図面で, ほぼ蘆花淺水荘の当初の状況を示しているものである。 主屋・仏堂（記恩堂）を中心に，庭園部分は，門から主屋玄関に 至る前庭・主屋内の坪庭・記恩堂への廊下と主屋の間にはさまれ た露地風の庭・主屋の東に大きく広がる主庭の 4 つに分けること ができるが，何といっても，注目すべきは主庭である。以下，こ の主庭について述べていきたい。

この主庭の主題が庭園の景色と園外景観である琵琶湖や対岸の 山々とが一体となった眺望であることは, 春擧が蘆花淺水荘で昭 和 3 年（1928）に詠んだ歌「もろ山の／中に一きは／近江富士／ 芽出度き春に/深みどりして」22) を持ち出すまでもなく, 明らか であろう。主屋客室からの写真 $3 \cdot 4$ (春擧撮影) に見るような 庭園と琵琶湖との視覚的な連続性は, いうまでもなく，その境界 に柵や塀などの障害物をいっさい作っていないことによる。この ことに関して『国際写真情報』昭和 6 年 8 月 1 日号 (国際情報社) に，面白いエピソードが掲載されているので紹介しておこう。筆 者は「神崎生」とある。「湖水と庭園との間には栅垣を設けず, 座敷からの眺めが直に大湖に通ずる所に特に主人の考案らしさが あるが, 或る人が是れでは泥棒が入るだろうと言ふと『私は隹ふ して大自然の眺めを泥棒しているのだから外から泥棒に入られて も五分五分です」と答へて設柵の勧めに応じなかった自慢の庭で ある。そして，これらの写真に見るように，芝生におおわれた 野筋状の築山が向かって左手前と右後方に重なって絶妙の稜線を 描き, その柔らかい線で庭園が琵琶湖と接するデザインは, 抜群 のものと評価できよう。

さらに, 平面図の琵琶湖に直接面するところに注目したい。護 岸石積を築き, その中央部に琵琶湖に降りる階段を設けている。 写真 5 に見るように, ここから直接, 琵琶湖へ舟遊びに出たので ある。この庭園は, 視覚的にだけでなく, 利用の面でも琵琶湖と 一体となっていたわけである。

次に, 流れに目を移そう。主屋の前面（東面）を北西から南東 へ斜めに横切る流れは, 芝生の広がりと相まって, この時代の庭 園らしい軽快さを感じさせるデザインである（写真 6$)$ 。水源は 井戸であった。主屋客室のちょうど正面付近に, この流れを横切 る沢飛石が打たれている。流れを渡る部分にだけ石を打ち，それ に連なる飛石はいっさい打たないことによって琵琶湖と一体となっ た眺望を損なわないデザインとしている点は秀逸である。この点 については, 重森三玲も高く評価している ${ }^{23)}$ 。しし, 主屋客室前 の沓脱石から飛石を連ねるようなことをしていたならば, 庭園の 景色は随分と矮小化されたものになっていたであろう。

もう一つ, 莎香亭付近の流れの岸辺のヨシにも注目しておきた い（写真 7$)$ 。春擧と夫人を撮ったこの写真には大正 8 年 (1919)
の注記があり, ヨシが主屋築造直後に配植されたものであること を示している。水辺のヨシは, 琵琶湖岸の典型的な景観であり, この地に生まれ育った春擧の原風景の一角をなしていたといって もよからう。ヨシの配植は, その原風景をモチーフとした春擧の デザインにほかならない。

ところで, 重森三玲が流れを横切る沢飛石のデザインを高く評 価していたことにはすでに触れた。それでは, 彼はこの庭園全体 についてはどう見ていたのか。彼の記述から引いてみよう。

「この地は, (中略) 東は琵琶湖を控へ, 湖水を隔てて遠く三 上山から飯道山付近に至る遠山の景を入れる地であって, かかる 地に庭園を築造するに当たって, この琵琶湖を背景とした借景庭 園は当然な結果である。併し本庭は只単に湖水を借景として用る たと云ふだけではあまりに言葉が足りないわけである。即ち湖水 を背景として, これを生かす為に春擧画伯自ら精進された四條派 的絵画的傾向をここに表現されたのである。云はが画伯の絵画が 庭園の形式をとって表はれたといふべきで, 只単なる当代自然主 義的庭園様式ではなく, そこに絵画的別途の様式が濃厚に表現さ れてるるのである。云はば自然主義的様式の上に更に絵画的様式 を加味したものである。(中略) 今本庭の地割を見るに, 湖水を 背景として二つの穏やかな小山を作り, この小山と書院の間を書 斎北面方向から南東記恩堂の東部へ流れる一条の小川を作り, 是 を観賞本位の様式として縓めてるるのである。仏堂や茶席又は待 合や四阿は本庭中に散在するが, 是は直接本庭と関係がある訳で はなく, 本庭としての眼目は, この小川の流れを通して小山を湖 水の景と調和させる点にある訳である。是は又一面平庭と築山と の折禹様式であると云ふことが出来るであらう。」」4)

重森は, 明治·大正時代の庭園一般に対し高い評価は与えてい ない(25)。しかしながら蘆花淺水荘の庭園については, 上記引用に 見るように,「自然主義的様式の上に更に絵画的様式を加味した もの」とその独特のデザインをかなり高く評価し, さらに, この 庭園を「庭園の形式をとった絵画」と評している。蘆花淺水荘の 作庭を絵画の創作になぞらえた春擧自身の文章等は残っていない。 しかし, 重森の指摘するような意識があったことは, 春擧自らが 撮影した前掲写真 3 ・4 などからもうかがえるところである。

また, 重森はこの庭園の主題が流れ（小川）や小築山（小山） などの庭景と琵琶湖や三上山など対岸の風景とが一体となった眺 望であり, 仏堂や茶席, 四阿などは庭園本来の主題とは無関係で あると指摘しているが，これもまた的確な指摘であるといえよう。

\section{5. 近代日本庭園史における蘆花淺水荘の意義}

春擧が蘆花淺水荘を築造したのとほほ同時期に, 京都では竹内 栖鳳が嵯峨野に別荘・霞中庵を営み (大正元年・1912〜), 橋本 関雪が銀閣寺にほど近い浄土寺石橋町に本邸・白沙村荘を開いて いる（大正 5 年 · 1916 ）。この時期, 京都の著名な日本画家の 間で, こうした別荘, 邸宅の築造がある種のブームであったとも いえよう。その背景として, 当時の京都画壇の隆盛と, それによ る一流画家の社会的地位の向上や経済力の充実があげられるが, 建物の普請や作庭が画家たちの創作意欲をそそる対象であったこ とも事実であろう ${ }^{26)}$ 。

蘆花淺水荘は, 春擧にとって京都の本邸に続く二度目の普請で 


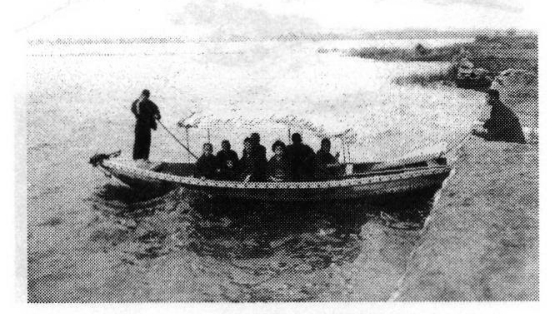

写真一 5 琵琶湖と直接面する

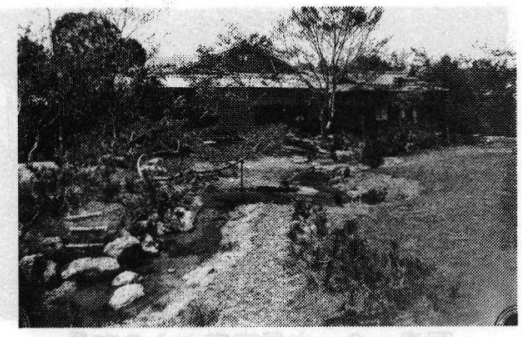

写真一 6 軽快な流れのデザイン

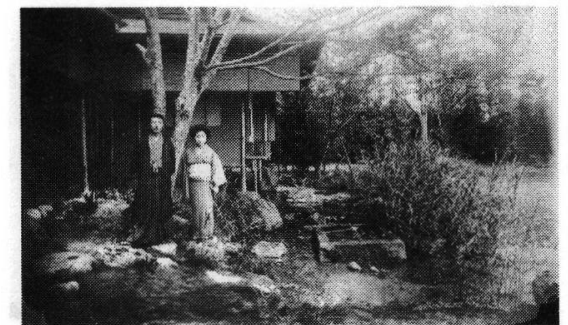

写真一 7 莎香亭前の水辺のヨシ（大正 8 年）
あり作庭であった。面積が限られた市中の本邸と違い，蘆花淺水 荘では琵琶湖や対岸の山々の風景と一体となった作庭が可能であっ た。しかも春擧の生地である。いわば自らの原風景を素材にした, 思いのままの作庭であった。石丸正運は春擧の芸術を,「確かな 写生力による華麗な風景画」と総括している ${ }^{277}$ が, この評は, そ のまま, 蘆花淺水荘の庭園にあてはめることができるのではなか ろうか。そして園外景観をとり入れたこの庭園が近代日本におけ る写実的風景式庭園 ${ }^{28)}$ として屈指のものであったこともまた間違 いのないところである。ただ, 園外景観と一体となった庭園であっ たがゆえに，近年の周辺環境の悪化による影響をまともに受けて しまったわけで，この点はかえすがえすも残念である。さいわい
敷地内は, 建物, 庭園ともに良好に保存されており, 滋賀県文化 財保護課による滋賀県近代和風建築調査でも, その価值は高く評 価された ${ }^{29)}$ 。そして, 庭園が大津市指定名勝となっているのに続 き,このたび建物も滋賀県の調査成果に基づき国の重要文化財 （建造物）に指定されることとなったのはまことに喜ばしい。

なお, 本稿は, 1993 年度の滋賀県近代和風建築調査に調査員 として参加した筆者が, その調査をもとに蘆花淺水荘の当主・山 元清秀氏から後日資料・写真の提供及びそれらについての説明を 受け, 考察を加えたものである。山元清秀氏の御教示, 御協力に 深く感謝いたします。なお, 本文及び補注では, 文体統一のため 敬称を省略したことをお断りします。

\section{参考文献}

1)『別荘入費及祝品控』に「大正三年九月 ヨリ控/参千壱百拾円・地処登記代共」の 記載がある。 2)山元清秀(1993): 父の趣 味の一面一琵琶湖畔の蘆花浅水荘: アサヒ グラフ別冊美術特集・山元春挙, p.94: 朝 日新聞社 3)明治・大正時代の京都の庭園 を特徵的に代表する南禅寺周辺の別荘庭園 群では，流れが好んで用いられる。これら の庭園の原型となった無隣庵のデザインの 軽快さがうけいれられたこととともに, 琵 琶湖疏水など水道関連施設やポンプの利用 によって豊富な水が確保できるようになっ たことがその要因となっている。4)山元 清秀談 5)山元清秀談。また, 重森三玲も 「施工は本位(ママ)政五郎氏であって, 氏 はまた春擧画伯の好みを忠実に表現すべく 努力されたのである。と記している（重 森三玲 (1936): 日本庭園史図鑑 21, P.30 31:有光社)。6) 山元清秀談 7)『別荘入 費及祝品控』に「(大正四年) 六月三拾壱 円・棟上祝儀」とある。 01 人 $=121$ 円 20 銭となり計算が合わない が, その原因は不明。9)現在の京都市山 科区を指すものか。10)京都府立総合資 料館編 (1971): 京都府統計史料集, p.230: 京都府。11)週刊朝日編 (1988): 值段史年 表, P.161:朝日新聞社。12)山元清秀談 13)山元清秀談 14)「植治」小川治兵衛 は, 住友吉左衛門の大阪茶臼山本邸（慶沢 園) の作庭を明治 $42 \sim 43$ 年 $(1909 \sim 10) に$
手がけている。さらに大正 7 年 (1918)に東 京で古河虎之助邸・西園寺公望邸などの作 庭を手がけたのを手はじめに, 東は東京か ら西は山口まで全国的な展開を見せる（尼 埼博正(1990): 植治の庭, p.160: 淡交社)。

15)当初は密植し, 間引きして景色を整 えていったという (山元清秀談)。1 16)春 擧は 25 才頃から京都天龍寺の峨山昌禎の もとに参禅し，禅に対する造詣が深かった。 そうした背景のもと, 禅僧とも深い交流が あった。17)春擧は, 蘆花淺水荘で年に 2〜3 回茶会を催した (山元清秀談)。18） 平井仁兵衛は清水の平井邸現『坂口』, 大 橋正之助は松ケ崎の無盡庵, 中井三郎兵衛 は岡崎の居然亭の施主。なお，春擧の交際 範囲の広さについては, 春擧の葬儀の時の 参列者の多さについての斎内一秀の述懐 (1993:毎日通いつめた十年間:アサヒグラ フ別冊美術特集 · 山元春挙, p.93: 朝日新 聞社) からも伺える。19)山元清秀談 2 0)春擧自らが作庭の構想を練っていたこと は「父の趣味の一面－琵琶湖畔の蘆花浅水 荘」(山元清秀(1993):アサヒグラフ別冊美 術特集・山元春挙, p.94:朝日新聞社) で も述べられている。21)重森三玲 (1936): 日本庭園史図鑑 $21, p .30 \sim 31$ : 有光社。な お, 同書は, 春擧の逝去の 3 年後に出版さ れたもので, 蘆花淺水荘についての記載は, 二次資料とはいえ, 資料的価值は高い。

22)早苗会編 (1935): 蘆花淺水, p.4:早苗会 23）「その中央の処で沢渡りを作ってあ
るが，それはほんとに実用と景とを兼ねて みながら，こ、で全体の飛石に接続させる ことは, 流れを遮ることになるので, 沢渡 りのみで，飛石を打たなかった手法の如き は驚くべき傑出した技術である。（重森三 玲:前掲書, p.32） 24)重森三玲:前掲書,p. 31 32 25)「明治以来の造園傾向を見 るに, 日本庭園の研究それ自体が斯くも阼 落してるた関係から，当代庭園はあまりに も葄落したのであって, 今日それらの明治 以後の庭園があまりにも貧弱であり，その 技術も亦甚だ筫しいものがあった。（重森 三玲:前掲書, p.15） 26)橋本関雪は「家」 (1935: 関雪随筆, p.195 201:中央美術社) のなかで「庭園を作り, 家を築くも一つの 創作とし見れば，吾が居も又た過渡期に於 ける習作に過ぎざるなり。と述べている。 27)「確かな写生力による華麗な風景画」 (石丸正運(1993): アサヒグラフ別冊美術特 集・山元春挙，p.86:朝日新聞社）28)総括 的に言うと, 江戸時代以前の日本庭園は, 自然風景をモチーフとしながらも象徵的 · 抽象的な手法で空間を構成してきた。明治 時代以後,こうした写意性を排し,写実的に かつ実物大で(園外景観も取り入れた)庭景 を構成する庭園が現れる。京都においては 山縣有朋の無隣庵がその先駆的・代表的な 実例である。このようなタイプの庭園を写 実的風景式庭園と呼ぶことを提唱しておき たい。29)滋賀県教育委員会編 (1994): 滋賀 県の近代和風建築, p.6:滋賀県教育委員会

Summary: YAMAMOTO Shunkyo(1871-1933) was a famous Japanese painter. Rokasensui-Soh was his villa on Lake Biwa at OtsuCity, which was his hometown. The garden of Rokasensui-Soh was constructed by MOTOI Masagoro, a gardener who lived in Kyoto, under the supervision of YAMAMOTO Shunkyo. It was a landscape-garden, including Lake Biwa as its important element not only visually but also functionally. YAMAMOTO Shunkyo must have designed the garden just like he painted landscape paintings. 